\author{
Jarosław TATARCZAK ${ }^{1}$ \\ Karolina SIEDLISKA ${ }^{2}$ \\ Robert KOSACKI ${ }^{3}$ \\ Jan M. OLCHOWIK ${ }^{4}$
}

\title{
ANALIZA WPLYWU ZACIENIENIA KRYSTALICZNYCH MODUŁÓW PV NA EFEKTYWNOŚĆ ENERGETYCZNĄ FARM SŁONECZNYCH
}

\begin{abstract}
Inwestycje związane z energetyką słoneczną posiadają stosunkowo długi czas zwrotu w odniesieniu do innych źródeł energii elektrycznej. Powodem tego są słabe uregulowania prawne wspierające rozwój tego rodzaju energetyki w Polsce. Jednak istnieją efektywniejsze sposoby pozyskiwania energii elektrycznej ze słońca, dzięki którym można znacznie skracać czas zwrotu tego typu inwestycji. Sposoby te można realizować już na etapie projektowania poprzez dobór modułów o wysokiej sprawności, odpowiedniego kąta ich nachylenia, czy też ograniczenie samo zacienienie modułów. W artykule został przeanalizowany wpływ cienia na moduły PV. Efekt cienia jest niekorzystnym zjawiskiem występującym podczas eksploatacji różnych systemów fotowoltaicznych, zarówno układów nadążnych, małych instalacji przydomowych, jak i dużych farm słonecznych. Zjawisko to powoduje zróżnicowanie poziomów napromieniowania słonecznego na powierzchni modułów, którego skutkiem jest obniżenie generacji energii elektrycznej. W najgorszym przypadku efekt cienia może wywołać trwałe uszkodzenie struktury ogniw, np. przez powstanie tzw. ,gorących punktów". Stosując odpowiednie algorytmy obliczeniowe, można przewidzieć skutki nieuniknionego zacienienia, a tym samym umożliwić podjęcie pewnych kroków zapobiegających występowaniu tego zjawiska już na etapie projektowania. Do tego celu służy analiza względnego ruchu słońca nad horyzontem przy uwzględnieniu typowych parametrów modułów fotowoltaicznych takich jak moc, długość czy szerokość oraz z ich kombinację ustawień na farmie fotowoltaicznej. Wyniki symulacji przedstawione w artykule pozwalają stwierdzić, w jaki sposób padający cień może wpływać na produkcję energii elektrycznej farmy słonecznej.
\end{abstract}

Słowa kluczowe: fotowoltaika, efekt cienia, efektywność energetyczna, promieniowanie słoneczne

\footnotetext{
${ }^{1}$ Jarosław Tatarczak, Uniwersytet Przyrodniczy w Lublinie, Katedra Maszyn Ogrodniczych i Leśnych, ul. Głęboka 28, 20-612 Lublin, +48 8153196 53, jaroslaw.tatarczak@ gmail.com.

${ }^{2}$ Karolina Siedliska, Uniwersytet Przyrodniczy w Lublinie, Katedra Fizyki, ul. Akademicka 13, 20-950 Lublin, +48 8144569 37, karolina.siedliska@gmail.com.

${ }^{3}$ Robert Kosacki, Politechnika Lubelska, ul. Nadbystrzycka 40B, 20-618 Lublin

${ }^{4}$ Autor do korespondencji/corresponding author: Jan M. Olchowik, Politechnika Lubelska, Instytut Inżynierii Odnawialnych Źródeł Energii, ul. Nadbystrzycka 40B, 20-618 Lublin, +48 81538 4700,j.olchowik@pollub.pl.
} 


\section{Wstęp}

Ogniwa słoneczne charakteryzują się stosunkowo niską gęstością generowanej mocy, zależną głównie od warunków nasłonecznienia i temperatury pracy modułów, a także prędkości wiatru i wilgotności powietrza. Promieniowane, które dociera do powierzchni modułów to nie tylko promieniowanie bezpośrednie, ale też i rozproszone, odbite między innymi od powierzchni ziemi i chmur. W szacowaniu energii promieniowania słonecznego docierającej do powierzchni modułów brany jest także pod uwagę kąt padania promieniowania słonecznego bezpośredniego oraz zacienienie ich powierzchni, co bezpośrednio przekłada się na ilość produkowanej przez nie energii elektrycznej.

Zacienienie modułów fotowoltaicznych jest zagadnieniem, które należy dokładnie rozważyć podczas projektowania elektrowni słonecznych. Zacienienie niewielkich powierzchni krystalicznych modułów fotowoltaicznych powoduje wyłączanie części lub całych ogniw, powstawanie tzw. gorących punktów (w miejscu zacienienia występuje gwałtowny wzrost temperatury związany przepływem prądu $\mathrm{w}$ przeciwnym kierunku, co może prowadzić nawet do zniszczenia modułów), a co za tym idzie spadek napięcia i znaczne obniżenie ilości produkowanej energii elektrycznej (zależność ta nie jest liniowa). Co więcej, w warunkach nierównomiernego nasłonecznienia krzywe mocy I-V mogą posiadać więcej niż jedno maksimum lokalne, stwarzając tym samym trudności w doborze odpowiedniego osprzętu dla elektrowni słonecznej.

Nie zawsze jednak udaje się całkowicie uniknąć zacienienia. Niemniej jednak istnieją metody, które pomagają zminimalizować starty z tym związane i ograniczyć ich wpływ na efektywność energetyczną farm słonecznych. Problemy te najlepiej rozwiązywać na etapie planowania rozmieszczenia modułów na danej powierzchni, poprzez analizę rocznych zmian kąta padania promieniowania słonecznego oraz konfiguracji cieni rzucanych przez sąsiednie moduły lub otaczające je elementy budynków, anteny, drzewa czy zalegający śnieg. Roczne straty spowodowane zacienieniem określa się nawet na poziomie $20 \%$ w przypadku systemów zintegrowanych z budynkami [1] lub w przypadku systemów wolnostojących od 30\% w miesiącu styczniu do 5\% w miesiącu lipcu [4], a spadek mocy nie jest wprost proporcjonalny do powierzchni zacienionej.

\section{Metodyka opracowanej analizy}

\subsection{Kąt odchylenia padania promieni słonecznych od powierzchni mo- dułu PV}

Głównym czynnikiem wpływającym na uzysk energii elektrycznej z modułów fotowoltaicznych jest ilość energii słonecznej docierającej do powierzchni modułu. Ilość ta jest ściśle związana z orientacją modułu względem kierunku padania promieni słonecznych. Wartość tę można bardzo łatwo określić zakła- 
dając, że strumień światła o szerokości i długości 1 metra padający prostopadle dostarcza do powierzchni ziemi określoną ilość energii stanowiącą 100\% energii strumienia światła. Jeżeli natomiast promienie słoneczne padają na powierzchnię ziemi pod kątem równym 45 stopni, wówczas ten sam strumień światła, wymaga już $1,41 \mathrm{~m}^{2}$ powierzchni. Oznacza to, że na określony obszar pada strumień światła o mniejszym natężeniu, co skutkuje dostarczeniem mniejszej ilości energii na jednostkę powierzchni absorbującej promieniowanie słoneczne [3], tak jak przedstawia to Rys. 1.

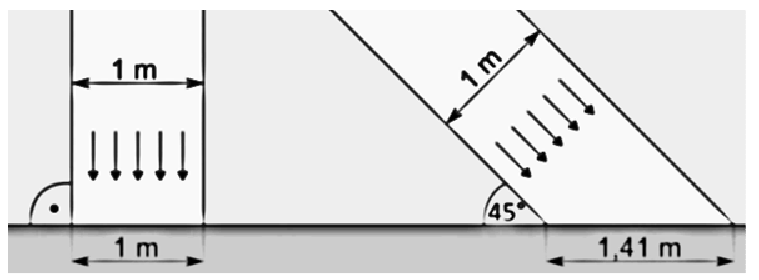

Rys. 1. Zależność szerokości padającego strumienia promieniowania słonecznego na powierzchnię ziemi przy wysokości pozornej słońca $0^{\circ}$ i $45^{\circ}$, względem ziemi

Fig. 1. The dependence of light beam radiation width on the ground surface at angles of incidence of $0^{\circ}$ and $45^{\circ}$

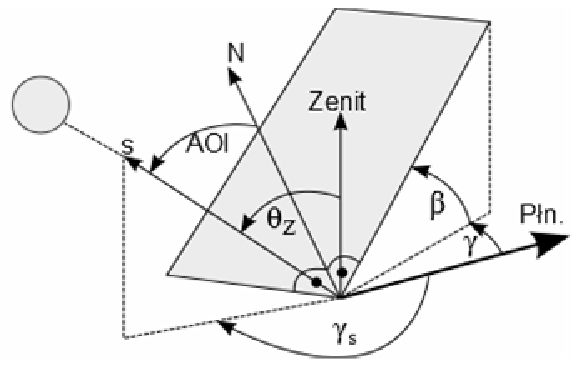

Rys. 2. Graficzna interpretacja wyznaczania kąta padania promieni do normalnej AOI

Fig. 2. A graphical interpretation shows how to determine the coefficient of the angel of incidence of normal AOI

Kąta padania promieni słonecznych na moduły fotowoltaiczne ma znaczny wpływ na generację energii elektrycznej. Wartość tą charakteryzuje kąt odchylenia promieni słonecznych od normalnej AOI ( $\mathrm{z}$ ang. Angle Of Incidence), którego ilustruje Rys. 2. i można ją obliczyć ze wzoru [2]:

$$
\cos (A O I)=\cos (\beta) \cdot \cos \left(\theta_{Z}\right)+\sin (\beta) \cdot \sin \left(\theta_{Z}\right) \cdot \cos \left(\gamma-\gamma_{S}\right)
$$

gdzie: $\beta$ - kąt nachylenia modułu, $\theta_{Z}$ - kąt zenitalny Słońca, $\gamma$ - kąt azymutalny modułu (założono do obliczeń: $0^{\circ}=$ północ, $90^{\circ}=$ wschód), $\gamma_{\mathrm{s}}-$ kąt azymutalny Słońca. 
a)
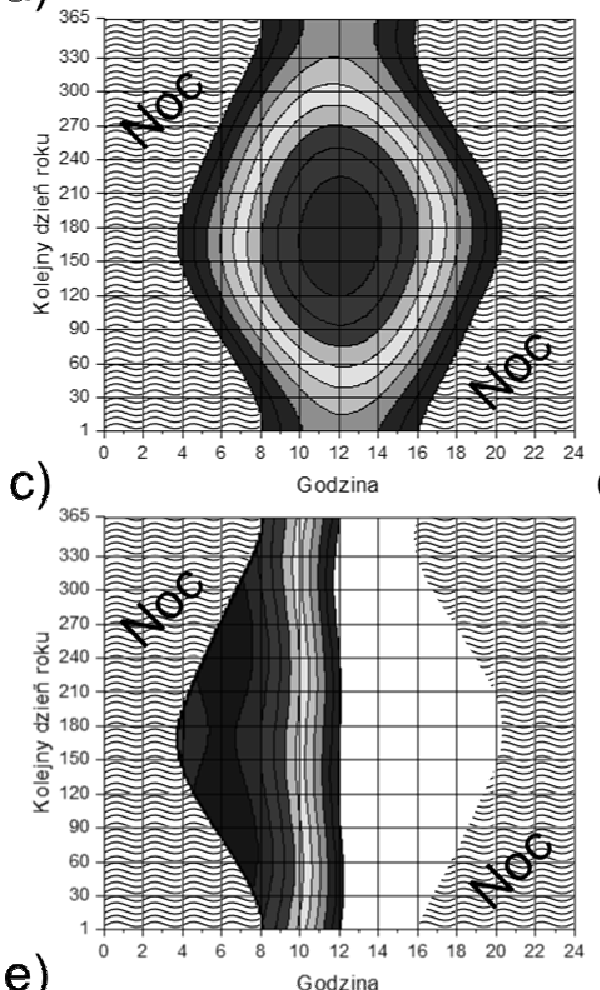

e)

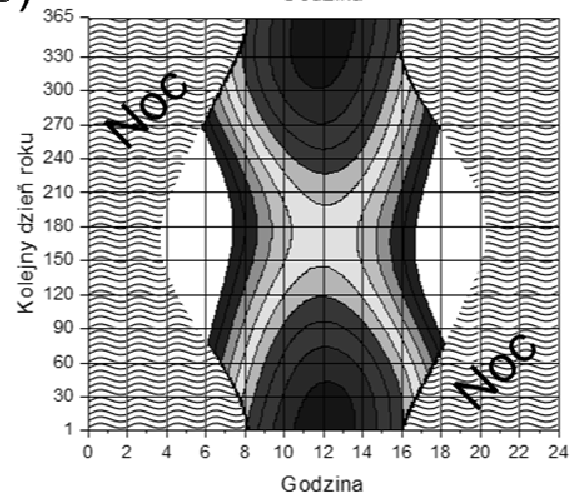

b)
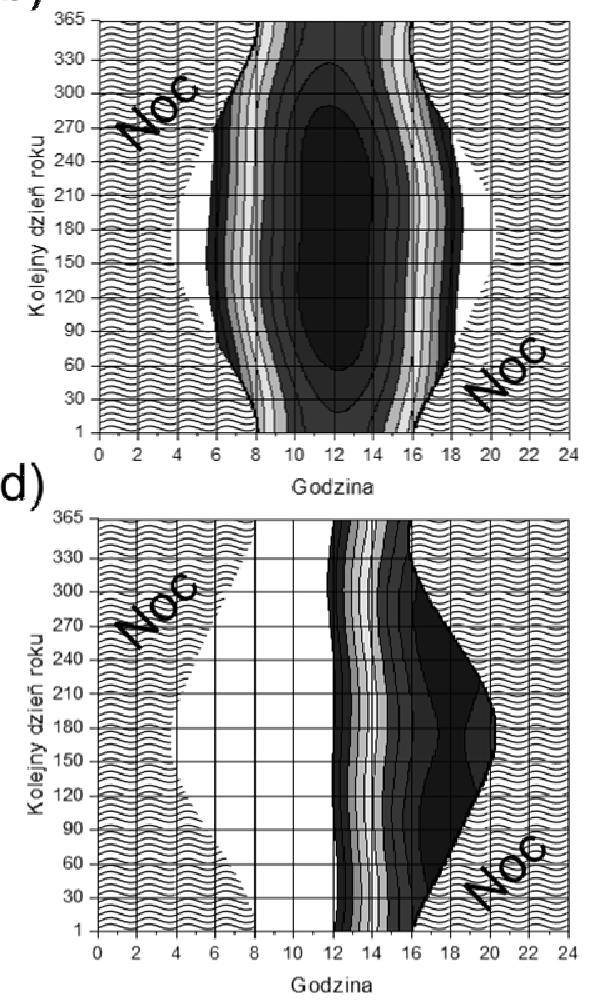

f)

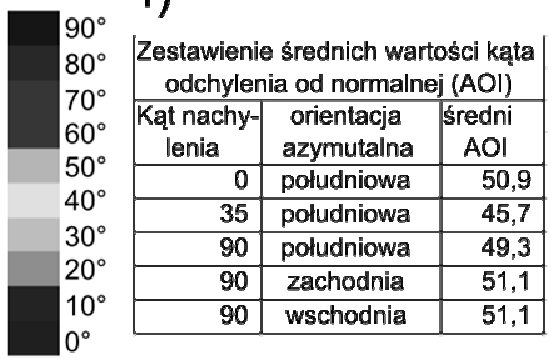

Rys. 3. Wykresy konturowe przestawiające procentowo wartość kąta odchylenia padającego promienia światła do normalnej powierzchni modułu dla warunków: a) $0^{\circ}$ nachylenia modułu, orientacja azymutalna południowa b) $35^{\circ}$, orientacja południowa c) $90^{\circ}$, orientacja wschodnia, d) $90^{\circ}$, orientacja zachodnia, f) $90^{\circ}$, orientacja południowa, f) tabela zestawiająca średnie wartości AOI

Fig. 3. Contour charts present the percentage value of the tilt angle of the incident light beam to the surface normal for the module: a) $0^{\circ}$ tilt module, azimuthal southern orientation b) $35^{\circ}$, southern orientation c) $90^{\circ}$, eastern orientation, d) $90^{\circ}$, western orientation, f) $90^{\circ}$, southern orientation, $\mathrm{f}$ ) table comparing the averages values of AOI 
Wartość kąta AOI przekłada się w znacznym stopniu na wartość energii słonecznej padającej bezpośrednio na ogniwo. Należy jednak mieć na uwadze fakt, że nie zawsze do powierzchni modułu dociera promieniowanie słoneczne bezpośrednie. Kąt AOI jest wskazówką pozwalającą w przybliżony sposób określić najkorzystniejszą opcję ustawienia modułów. Na podstawie algorytmu umożliwiającego obliczenie pozycji Słońca oraz wzoru (1) sporządzono wykresy konturowe obrazujące wartości kątów AOI w zależności od godziny i kolejnych dni w ciągu roku dla miasta Lublina. Przedstawione są one na Rys. 3.

$\mathrm{Na}$ podstawie otrzymanych wyników stwierdzono, że najkorzystniejszym kątem nachylenia modułu PV względem powierzchni ziemi jest kąt $35^{\circ}$. Dzieje się tak, ponieważ promieniowanie słoneczne w tym przypadku pada przez najdłuższy okres w ciągu roku pod kątem bliskim $0^{\circ}$. , a tym samym dostarczane jest najwięcej energii promieniowania bezpośredniego i największy hipotetyczny uzysk energii. W przypadku kąta AOI o wartościach bliskich kątowi $90^{\circ}$ należy się zastanowić, czy wartość ta nie wynika z zacienienia wynikającego z samego ustawienia modułu.

\subsection{Udział energii rozproszonej w generacji energii elektrycznej}

$\mathrm{W}$ celu dokładniejszej analizy uzysku energii z modułów fotowoltaicznych, należy także uwzględnić promieniowanie rozproszone. Absorpcja promieniowania rozproszonego jest zależna od typu modułów PV i dostępnego obszaru nieba, w obrębie którego promienie mogą zostać odbite od chmur i dotrzeć do powierzchni modułu. Przy ustawieniu modułów w pozycji horyzontalnej promieniowanie słoneczne odbite od chmur, padające na ogniwa dociera do nich z całego obszaru nieba. Natomiast przy ustawieniu modułu pod kątem prostym do powierzchni ziemi (np. zamocowany do ściany budynku) obszar nieba, z którego zbierane jest promieniowanie zmniejsza się o około 50\%. Oznacza to, że przy prostopadłym ustawieniu na moduł będzie padać mniejsza ilość energii rozproszonej niż na powierzchnię poziomą.

Program PV GIS[5] pozwala przeprowadzić symulację ilości uzyskanej energii elektrycznej z modułów PV, a także ilość energii docierającej do powierzchni modułów (nasłonecznienie). W programie tym zasymulowano ilość energii słonecznej rozproszonej docierającej do modułu ustawionego w pozycji poziomej, jak i pod kątem 90 stopni do powierzchni ziemi. W przypadku ustawienia modułu w pozycji pionowej roczna suma energii rozproszonej padająca na daną powierzchnię wyniosła $358,81 \mathrm{kWh} \cdot \mathrm{m}^{-2}$, co stanowiło $62 \%$ rocznej sumy energii dla pozycji poziomej, czyli $574,65 \mathrm{kWh} \cdot \mathrm{m}^{-2}$ (obliczenia dla lokalizacji Lublin). Wyniki symulacji przedstawiono w Tabeli 1. 
Tabela 1. Wartości napromieniowania dla miasta Lublina na podstawie danych portalu PVGIS [5] Table 1. Solar irradiation data for the Lublin city from the PVGIS website are as follows [5]

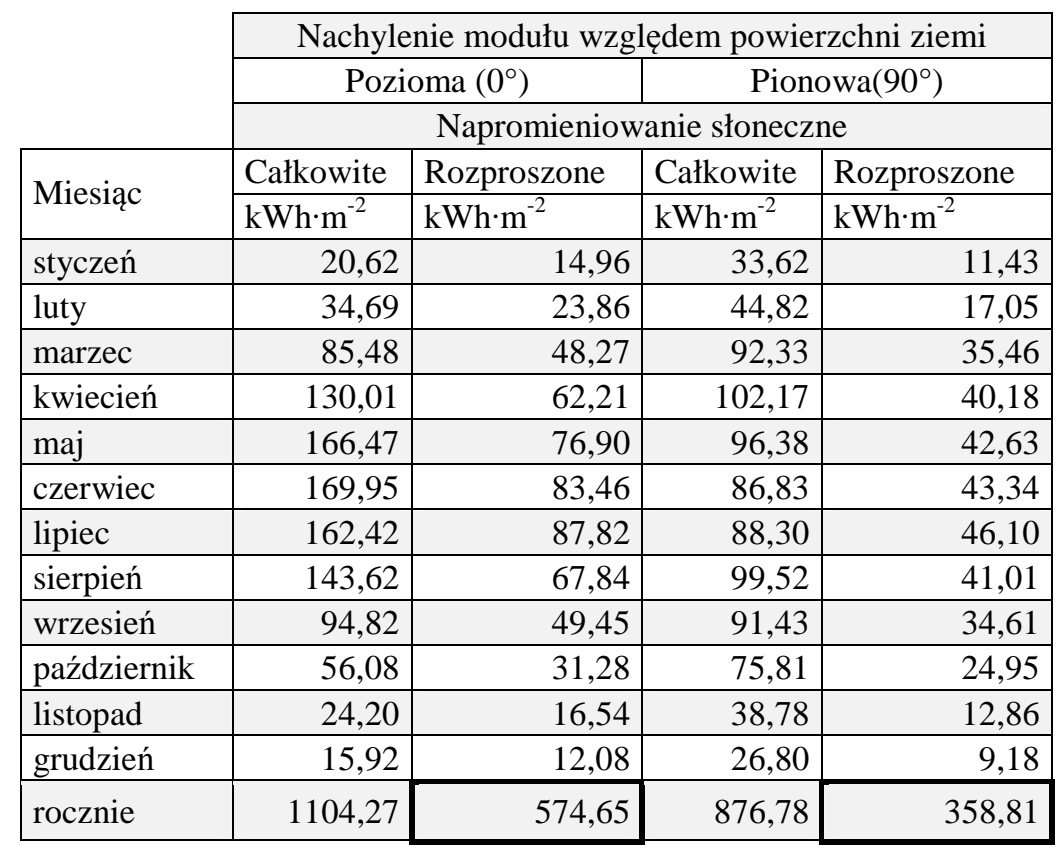

\subsection{Efekt cienia}

Wpływ zacienienia ma duże znaczenie na pracę instalacji fotowoltaicznych. Nieprawidłowe dobranie odstępów pomiędzy rzędami, czy ustawienie modułów tuż za przeszkodą może spowodować wyłączenie z pracy pewnej sekcji modułów lub całej instalacji PV. Taka sytuacja może się zdarzyć w sezonie zimowym, kiedy to pozorna wysokość Słońca nad horyzontem jest dużo mniejsza niż latem. Dla porównania dla Lublina długość cienia rzucanego przez słup o wysokości $2 \mathrm{~m}$ w porze południa w najkrótszym dniu roku będzie wynosić ok $7 \mathrm{~m}$, natomiast w najdłuższym nieco powyżej jednego metra.

Przy założeniu, że optymalny kąt nachylenia modułu wynosi $35^{\circ}$, a wysokość słońca w porze najkrótszego dnia roku w czasie południa około $15^{\circ}$ można określić szacunkowe równanie na wartość odstępu pomiędzy kolejnymi rzędami baterii słonecznych:

$$
p=\frac{h}{\tan \beta}=\frac{\sin \alpha \cdot d}{\tan \beta}=\frac{\sin 35 \cdot d}{\tan 15} \approx 2,14 \cdot d
$$

gdzie: $\alpha$ - kąt nachylenia modułu względem ziemi, $d$ - długość modułu PV, $\beta$ - kąt określający wysokość słońca nad linią horyzontu. 
Najczęstsze ustawienie modułów PV na farmach słonecznych to mocowanie dwupoziomowe pionowe, takie jak pokazano na Rys. 4. Przyjmując, że przeciętna wielkość modułów PV to $1650 \times 990 \mathrm{~mm}$ (moc $230 \mathrm{~W}$ ) oraz podstawiając te dane do wzoru (2) można obliczyć, że optymalna odległość, gwarantująca zimą brak zacienienia modułów w południe i jednocześnie minimalizująca rozmiary farmy słonecznej, wynosi około $7 \mathrm{~m}$.

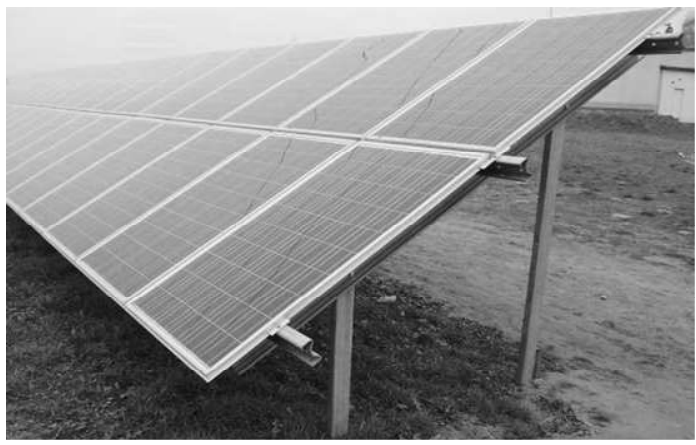

Rys. 4.Ustawienie modułów na farmie fotowoltaicznej w Wierzchosławicach

Fig. 4. An arrangement of modules at the photovoltaic farm in Wierzchoslawice

W przypadku tradycyjnych modułów krystalicznych częściowe zacienienie modułów nie przekłada się w sposób liniowy na spadek uzysku energii elektrycznej, czego powodem jest sposób łączenia ogniw wewnątrz modułu. Prawie wszystkie moduły fotowoltaiczne, produkowane w technologii mono- i polikrystalicznej, posiadają diody bocznikujące. W zależności od modelu ilość diod może być różna. Najczęściej występuje kombinacja 1 lub 3 diodowa. Przy jednodiodowym modelu wystarczy, ze kilka ogniw zostanie zacienionych, a cały moduł zostanie ,wyłączony”. W przypadku, gdy moduł posiada np. 3 diody bocznikujące to przysłonięcie kilku ogniw spowoduje „wyłączenie” tylko jednej bądź dwóch sekcji. Istotne jest to zwłaszcza w przypadku farm fotowoltaicznych, gdzie moduły są montowane $w$ wielu rzędach. Prawidłowe ustawienie modułów pozwoli ograniczyć niekorzystny wpływ zacienienia na moduły. Sugerowanym rozwiązaniem jest ustawianie modułów w pozycji horyzontalnej, ponieważ takie rozwiązanie pozwala na pracę nawet przy częściowym zacienieniu.

\section{Symulacja zacienienia}

Symulacja ma na celu przeanalizowanie, w jaki sposób ustawienie modułów oraz odstępów miedzy rzędami wpływa na procentowe zacienienie farmy fotowoltaicznej. Do symulacji przyjęto następujące założenia: podstawowa 
jednostka robocza to moduł fotowoltaiczny o mocy $230 \mathrm{Wp}$ i wymiarach $165 \times 99 \mathrm{~cm}$ w ilości 4360 sztuk (1,0 MWp), 10 rzędów, dwa stopnie pionowego ułożenia modułów oraz kąt nachylenia względem ziemi $35^{\circ}$. Wyniki symulacji przedstawiono na Rys. 5.

a)

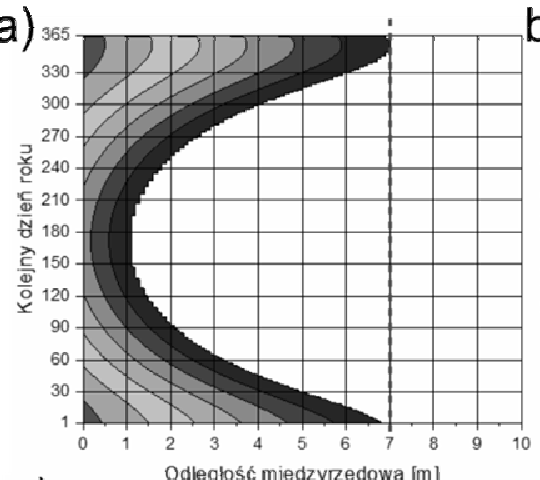

c)

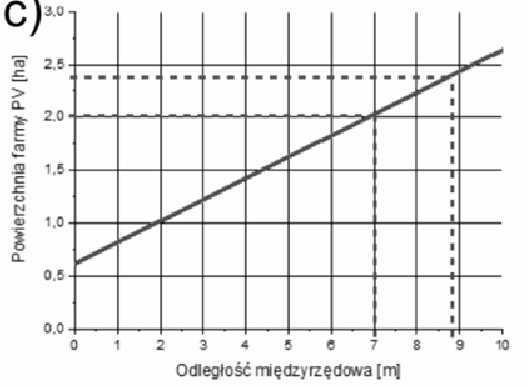

b) 3

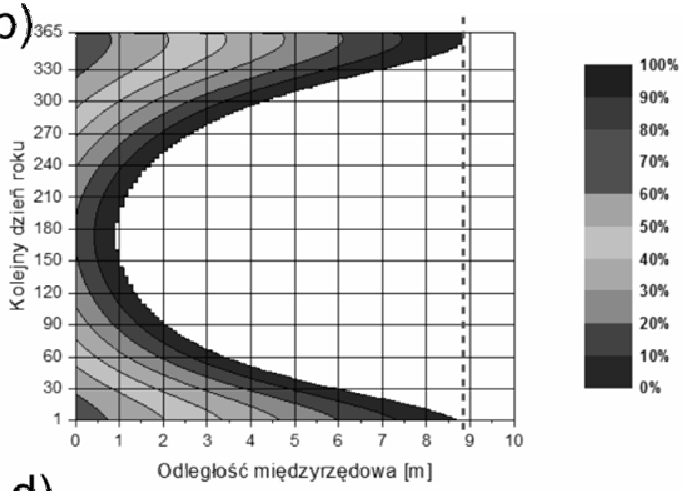

d)

\begin{tabular}{|c|c|c|c|c|}
\hline \multicolumn{2}{|c|}{$\begin{array}{l}\text { Przedziały w których } \\
\text { calkowano }\end{array}$} & \multirow{2}{*}{$\begin{array}{c}\text { Nastonecznienie } \\
\text { w danym } \\
\text { zakresiet }\end{array}$} & \multirow{2}{*}{$\begin{array}{c}\text { Naslonecrnienıe } \\
\text { calkowite }\end{array}$} & \multirow{2}{*}{\begin{tabular}{|l} 
Udzial nasli, w \\
danym zakresice \\
do catkowiteggo
\end{tabular}} \\
\hline & Rozpictost' & & & \\
\hline Lakres & godz. & $\mathrm{kWh} / \mathrm{m} 2$ & $\mathrm{kWh} / \mathrm{m} 2$ & $\%$ \\
\hline 11:30-12:30 & 1 & 164,57 & \multirow{6}{*}{1273.77} & 12,92 \\
\hline 11:00-13:00 & $\underline{2}$ & 326,17 & & 25,61 \\
\hline 10:30-13:30 & 3 & 481,78 & & 37,82 \\
\hline $10: 00-14: 00$ & 4 & 628,64 & & 49,35 \\
\hline 9:30-14:30 & 5 & 763,97 & & 59,98 \\
\hline $9: 00-15: 00$ & 6 & 885,21 & & 69,50 \\
\hline
\end{tabular}

Rys. 5. Wyniki symulacji procentowego zacienienia farmy PV zlokalizowanej w pobliżu Lublina: a) wykres konturowy przedstawiający procentowe zacienienie w godzinach południowych w zależności od wartości odstępów międzyrzędowych, b) zacienienie dla godzin 10:00 i 14:00 c) zależność odstępów między rzędami do powierzchni farmy PV, d) nasłonecznienie na powierzchnię w odpowiednich przedziałach czasowych

Fig. 5. Simulation results of percentage shading on PV farm located near Lublin: a) contour plot showing the percentage shading at midday depending on the spacing between the rows, b) shading for hours from 10:00 to 14:00 c) the dependence of the spacing between rows on PV farm to the farm area, d) the surface of the insolation at time intervals

Wyniki symulacji pozwalają w graficzny sposób wyznaczyć optymalną odległość międzyrzędową na famie PV. Dla godziny 12:00, czyli południa minimalna odległość międzyrzędowa, dla której nie występuje efekt zacienienia wynosi 7 metrów. Należy jednak mieć na uwadze szerszy przedział czasowy, gdyż w godzinach od 10:00 do 14:00 na moduł pada prawie 50\% całkowitej rocznej sumy energii słonecznej, co jest widoczne na Rys. 5d. Dostosowanie się do powyższych kryteriów wiąże się zazwyczaj z powiększeniem powierzchni działki o $20 \%$. 
Straty energii elektrycznej w sposób wykładniczy zależą od odległości miedzy rzędami. Przy odległości 7 metrów straty energii elektrycznej wynoszą ok. 2,5\% (Rys. 6.), a powierzchnia działki wynosi nieco ponad 2 ha. Straty przy odstępach powyżej 7 metrów są już mało znaczące. Jedynie w porze zimowej wpłyną negatywnie na uzysk energii elektrycznej.

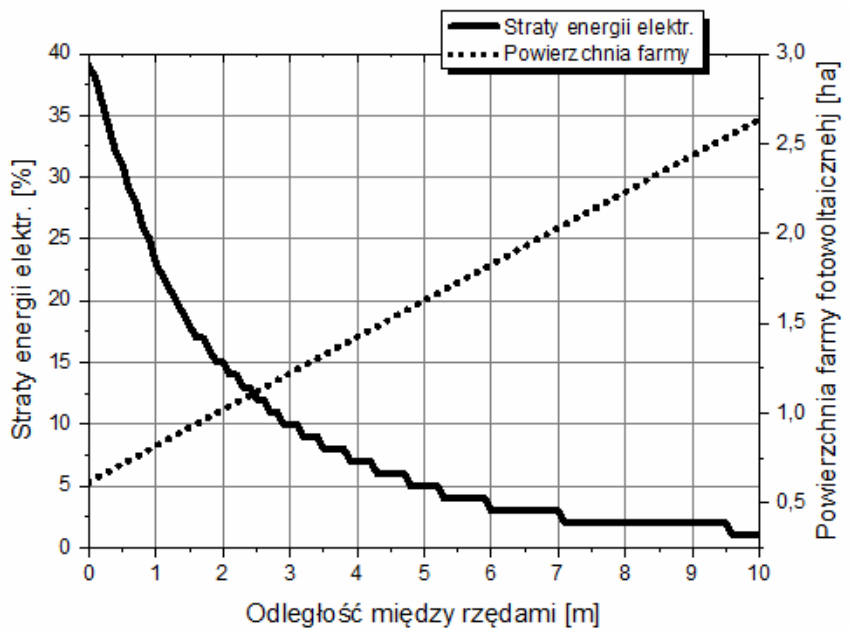

Rys. 6. Straty energii elektrycznej farmy PV w zależności od odległości międzyrzędowych (symulacja dla Lublina i zadanych parametrów)

Fig. 6. It shows the loss of electric potential energy depending on the distance between the rows (the simulation for Lublin and the specified parameters)

\section{Podsumowanie}

Krystaliczne moduły fotowoltaiczne są bardzo wrażliwe na zacienienie. Nawet niewielki zacieniony obszar może powodować wyłączenie sekcji ogniw lub całego modułu, a także gwałtowny wzrost temperatury związany z wstecznym przepływem prądu przez ogniwo. Obniżenie sprawności ogniw słonecznych wraz $\mathrm{z}$ temperaturą oraz stopniem zacienienia jest czynnikiem bardzo istotnym przy optymalizacji warunków pracy systemów fotowoltaicznych.

W niniejszej pracy przedstawiono, w jaki sposób można określić optymalne położenie modułów słonecznych tak, aby docierała do niech jak największa ilość promieniowania słonecznego, a zacienienie związane z położeniem sąsiednich baterii słonecznych było jak najmniejsze. Wiedza ta może być przydatna przy prognozowaniu uzysku energii elektrycznej, projektowaniu farm fotowoltaicznych, czy sporządzaniu planów biznesowych inwestycji. 


\title{
Literatura
}

[1] Jahn U., Tregtmeyer D., Grochowski J., Auswertungenausdem 1000-Dächer PV Programme: Vergleischsmessungen an PVGeneratoren. Proc., 10th Symposium PhotovoltaisheSolarenergie, Staffelstein, Germany 1995, s. 66-77.

[2] King D. L., Kratochvil J. A., Boyson W. E., Measuring Solar Spectral and Angle-ofIncidence Effects on Photovoltaic Modules and Solar Irradiance Sensor, 26th IEEE Photovoltaic Specialists Conference, Wrzesień 1997, Anaheim, California.

[3] Markvart T., Fragaki A., Ross J.N., PV system sizing using observed time series of solar radiation, Solar Energy 80, 2006, s. 46-50.

[4] Picault D., Raison B., Bacha S., Aguilera J., De La Casa J., Reducing mismatch losses in grid-connected PV systems by the means of alternative array topologies, Technical handbook 11a'10, 2010, s. 1-6.

[5] Program stworzony w ramach projektu Komisji Europejskiej, dostępny pod adresem http://re.jrc.ec.europa.eu/pvgis/.

\section{THE ANALYSIS OF THE SHADING IMPACT ON PV CRYSTALLINE MODULES FOR THE ENERGY EFFICIENCY OF SOLAR FARMS.}

\begin{abstract}
S u m m a r y
Investments related to solar energy have a relatively long payback period in relation to other sources of electricity. The reason for this is problem are poor law regulations to promote the development of this type of energy in Poland. The payback period of solar energy investments is very long. The reason for this is the problem of weak regulation which support the development of this type of energy in Poland. However, there are effective methods to obtain electricity from the sun - the methods by which you can significantly shorten the time of reimbursement of capital expenditures. These methods can be implemented at the design stage by the selections of highefficiency module and the proper angle of inclination, or by the reduction of the self-shading effect for modules. The article examined the impact of shadow on modules (a shadow effect). The shadow effect is a negative phenomenon for the different photovoltaic systems, starting from tacking systems, passing the large-scale solar farms and ending with the small domestic installations. This phenomenon causes the differentiation levels of the solar irradiation on the surface of modules and results in a decrease in generation of the electric potential energy. In the worst case scenario, the shadow effect can cause permanent damage to the structure of the solar cells - e.g. by creating so-called "hot spots". Using appropriate calculation algorithms, you may predict the effects of unavoidable shading, and thereby it allow you to take certain steps to prevent the occurrence of this phenomenon at the design stage. For this purpose the analysis of the relative movement of the sun above the horizon with taking into account the typical parameters of photovoltaic modules, such as power, length or width, and their combination of settings for a given photovoltaic farm. The simulation results, which are presented in the paper, enable reader to understand how to shadow can affect on the electricity production.
\end{abstract}

Keywords: photovoltaic, shadow effect, electrical efficiency, solar radiation

Przestano do redakcji: 11.12.2014 $r$.

Przyjęto do druku: 22.06.2015 r.

DOI:10.7862/rb.2015.79 